\title{
Pearl Jumeira project: a case study of land reclamation in Dubai, UAE
}

\author{
Marwan Alzaylaie ${ }^{\text {i) }}$ and Aly Abdelaziz ii) \\ i) Principal Geotechnical Engineer, Dubai Technology and Media Free Zone Authority, Government of Dubai, P.O. Box 478844, Dubai, \\ UAE \& PhD Researcher, Institute and Laboratory of Geotechnics, Faculty of Civil Engineering and Geodesy, Technical University of \\ Darmstadt, Petersen strasse 13, 64287 Darmstadt, Germany \\ ii) Technical Manager, Al Hai \& Al Mukaddam for Geotechnical Works, P. O. Box 60462, Dubai, UAE.
}

\begin{abstract}
Pearl Jumeira is an artificial offshore land formation located in Jumeira Beach in the Arabian Gulf and is constructed from Dubai-sourced reclaimed sand and locally sourced rockworks. Reclaimed sand was dredged from known borrow pits in Dubai waters. The island will cover approximately 8.3 million square feet of land (fully serviced with all infrastructure requirements) consisting of more than 3.0 million square feet of residential villa plots and over 90,000 square feet of retail, community, and educational facilities. The current paper presents a geotechnical case study on this reclaimed island in terms of: The geotechnical design, the construction stages, and the ground investigation results. In the geotechnical design stage, soil properties of the reclaimed land were investigated to achieve the design bearing capacity and to assess the risk of liquefaction. In the geotechnical construction stage, soil improvement technologies such as vibro compaction and surface compaction were used. In the soil investigation stage, a set of soil tests were conducted in order to achieve the geotechnical design. These tests include Standard Penetration Test (SPT), Unconfined Compressive Strength Test (UCS), Piezocone Penetration Tests (CPTU), Zone Load Test, Particle Size Distribution (Sieve Analysis), etc.... The thickness of the reclamation fill varies across the site but is typically in the order of $10 \mathrm{~m}$ to $15 \mathrm{~m}$ and consists primarily of clean sand with lenses of silty materials. The materials below the pre-reclamation seabed comprise of layers of sand and silty materials of varying thicknesses, underlain by the Calcisiltite/Calcarenite bedrock between $-10 \mathrm{~m}$ and $-15 \mathrm{~m}$ Dubai Municipality Datum (DMD).
\end{abstract}

Keywords: reclamation, soil improvement, liquefaction, geotechnical design

\section{INTRODUCTION}

Meraas Development LLC (Meraas) is developing the "Pearl Jumeira", off the Dubai Coastline. The site for the proposed development is situated adjacent to the Jumeira 1 shoreline north of Jumeira public beach, near the intersection of Al Dhiyafa Road and Jumeira Beach Road. To the west of the site is the World Islands and to the north are the Dubai Dry Docks and Dubai Maritime City. The proposed development will be a reclaimed island of approximate area 8,300,500 Sq.ft.

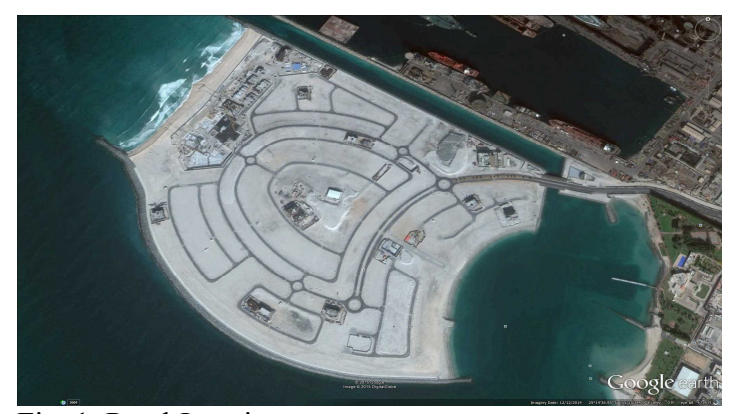

Fig. 1. Pearl Jumeira

The Pearl Jumeira is constructed from Dubai sourced reclaimed sand and locally sourced rockworks.
Reclaimed sand was dredged from known borrow pits in Dubai waters, transported to site and deposited on the seabed to form the development. The sand is retained along the perimeter of the development with rockwork slopes and man-made beaches (edge structures). The edge structures are designed to provide shoreline stability and a seaward defense to the upland areas. The reclaimed material was improved via vibro-compaction to provide a suitable bearing surface for the future development.

To improve the geotechnical characteristics of the land for future development, extensive dynamic compaction has been carried out on the reclaimed fill. The Final Geotechnical Assessment and Design Report [1] includes detailed descriptions and evaluations of all relevant geotechnical tests carried out during the course of this project as well as recommendations for future construction of building foundations. The thickness of the reclamation fill varies across the site but is typically in the order of $10 \mathrm{~m}$ to $15 \mathrm{~m}$ and consists primarily of clean sand with lenses of silty materials. The lenses of silty materials are present only in portions of the site in thicknesses generally between $0 \mathrm{~m}$ and $0.4 \mathrm{~m}$, but up to approximately $1.5 \mathrm{~m}$ at one (1) isolated location. The 
silty material has been analyzed and described extensively in this report and it is concluded that it has very little significance in relation to future developments.

The materials below the pre-reclamation seabed consist of layers of sand and silty materials of varying thicknesses, underlain by the Calcisiltite/Calcarenite bedrock between $-10 \mathrm{~m}$ and $-15 \mathrm{~m}$ DMD. The strength and stiffness properties of the sand and silty seabed materials were improved during the extensive dynamic compaction campaign. Based on the test results, it is concluded that the soil materials across the Pearl Jumeira site were treated and compacted according to the specification requirements and the improved ground is therefore suitable for further development. The master plan for Pearl Jumeira consists of plots with varying development plans. In addition, the Pearl Jumeira includes varying site conditions, particularly along the development perimeter and therefore the site is divided into a number of building zones.

Construction guidelines related to the construction of foundations are presented for each building zone considering site specific conditions and development relevant for each zone. Analysis provided for foundations is valid only if the provided guidelines are strictly followed.

\section{PRE-RECLAMATION GEOTECHNICAL INVESTIGATION}

The pre-reclamation geotechnical investigation carried out on the Pearl Jumeira project was mainly an off-shore investigation and comprised in the initial phase of only 5 boreholes, namely BH-29, BH-30, BH-31, BH-32 and BH-37. Upon completion of the initial phase, an additional geotechnical investigation was carried out within the Pearl Jumeira boundaries and comprised of BH-58, BH-73, BH-74, BH-75, BH-76, BH-77, BH-78, BH-79 and BH-80. With the exception of BH-32 \& BH-80, seabed was encountered at an elevation of about $-10.0 \mathrm{~m}$ DMD during the pre-reclamation off-shore investigation. The seabed comprised in general of very weak to weak, fine to coarse grained CALCARENITE layers down to an elevation of $-35.5 \mathrm{~m}$ DMD (revealed/recorded in BH-58 and BH-73) becoming SANDSTONE down to an elevation of $-36.5 \mathrm{~m}$ DMD in $\mathrm{BH}-58$ and cemented SAND down to $-37.5 \mathrm{~m}$ DMD in BH-73 beyond that the sub-surface comprised of CALCISILTITE down to $-40.5 \mathrm{~m}$ DMD, locally interbedded with cemented sand at elevations of $-10.5 \mathrm{~m}$ to $-11.5 \mathrm{~m}$ and $-19.5 \mathrm{~m}$ to -20.0 $\mathrm{m}$ in BH-31 and between $-16.5 \mathrm{~m}$ to $-18.0 \mathrm{~m}$ in BH-73. The SAND layer encountered in the seabed is encountered in lenses and is localized in nature.

Ground surface was struck in BH-32 at an elevation of $-2.5 \mathrm{~m}$ DMD whilst it was struck in BH-80 at $-7.0 \mathrm{~m}$ DMD, and comprised of SAND down to $-11.5 \mathrm{~m}$ DMD locally interbedded by a thin layer of CALCIRUDITE.
Table 1 below represents the general stratigraphy of the pre-reclaimed sub-surface condition.

Table 1: General stratigraphy of the pre-reclaimed sub-surface condition

\begin{tabular}{|l|l|l|}
\hline $\begin{array}{l}\text { Elevation } \\
\text { DMD }(\mathrm{m})\end{array}$ & Description & Remarks \\
\hline-7.0 to \\
-10.5 & $\begin{array}{l}\text { Cemented } \\
\text { silty SAND }\end{array}$ & $\begin{array}{l}\text { This strata was only revealed in BH-32 } \\
\text { and BH-80 as the seabed was } \\
\text { encountered at high elevations }\end{array}$ \\
\hline $\begin{array}{l}-10.5 \text { to } \\
-38.0\end{array}$ & $\begin{array}{l}\text { CALCARE- } \\
\text { NITE }\end{array}$ & $\begin{array}{l}\text { Becoming SANDSTONE between }-35.5 \\
\text { to }-36.5 \text { in BH-58 and cemented SAND } \\
\text { between }-34.5 \text { to }-37.5 \text { in BH-73 }\end{array}$ \\
\hline $\begin{array}{l}-38.0 \text { to } \\
-40.5\end{array}$ & $\begin{array}{l}\text { CALCISIL- } \\
\text { TITE }\end{array}$ & Revealed in BH-58 and BH-73 \\
\hline
\end{tabular}

\subsection{Cemented Silty SAND}

This layer is classified as dense to very dense slightly silty to silty calcareous SAND with associated silt fragments and slight cementation. The cemented silty SAND has identical composition to the marine silty sand, but this layer exhibits partial cementation as normally expected in digenetic process of sedimentation. In few boreholes, this layer can be found as an inter-layer of the underlying and overlying CALCARENITE bedrock at elevation ranging from $-9.5 \mathrm{~m}$ to $-16.0 \mathrm{~m}$ DMD and thickness from $0.1 \mathrm{~m}$ to $1.5 \mathrm{~m}$.

\subsection{CALCARENITE}

The CALCARENITE is a geological nomenclature of calcareous SANDSTONE. The carbonate $\left(\mathrm{CaCO}_{3}\right)$ enrichment associated in the digenetic process has enhanced the lithification of this rock unit; however, the CALCARENITE is still in its youthful state of lithification and classified as very weak to weak, fine to coarse grained siliceous, slightly silty to silty calcareous SANDSTONE (CALCARENITE) with slightly cemented to partially cemented inter-layers of SAND, fractures are close to medium with rough sub horizontal planar. This layer is recognized as the bedrock

\subsection{CALCISILTITE}

The CALCISILTITE is a geological nomenclature of calcareous SILTSTONE. The carbonate $\left(\mathrm{CaCO}_{3}\right)$ enrichment associated in the digenetic process has enhanced the lithification of this rock unit. The CALCISILTITE is still in its youthful state of lithification and classified as very weak to weak light grey to off-white calcareous SILTSTONE (CALCISILTITE) with occasional shell and coral fragment, fractures are close to medium with rough sub horizontal planar. The CALCISILTITE is situated below or embedded within the CALCARENITE.

\section{PROJECT CONSTRUCTION SEQUENCES AND IMPROVEMENT WORK}

The scope of work includes: Dredging and reclamation; soil improvement; leveling and 
compaction; and supply and placing of rock revetments.

Dredging and reclamation: Land reclamation realized with sand from assigned borrows areas as per client indication by means of TSHD (trailer suction hopper dredge). Mainly in two phases:

- $\quad 1$ st phase - free dumping/discharge on the footprint of the project, central portion only and Limited to the underwater levels.

- $\quad$ 2nd phase - hydraulic backfilling to design level after the completion of rock revetment.

Rock revetment: As rock revetment is intended the outside protection of reclamation. All activities performed either during day or night shift.

Ground improvement: Ground improvement and densification of reclamation fill has been carried out using a suitable deep compaction technique, such as the Vibro or Deep compaction then followed by the surface compaction and levelling.

\section{GEOTECHNICAL INVESTIGATIONS BEFORE SOIL IMPROVEMENT (PRE-COMPACTION)}

The final post treatment level for Pearl Jumeira is constructed from approximately $10 \mathrm{~m}$ to $15 \mathrm{~m}$ thick reclaimed granular fill material. The geotechnical investigation carried out for this phase comprised of 18 drilled boreholes after the reclamation works and prior to the improvement works. Pre-compaction cone penetration tests were carried out in each $50 \mathrm{~m} \times 50 \mathrm{~m}$ square across the project site before compaction.

\section{GEOTECHNICAL INVESTIGATIONS AFTER SOIL IMPROVEMEN (POST-COMPACTION)}

The reclaimed granular fill material in addition to the existing granular sandy layer below the seabed were subjected to post-reclamation ground improvement to improve the strength and compressibility fill characteristics. The improvement/compaction was performed in to two (2) phases;

1. Deep vibro-compaction conducted according to a $4.2 \mathrm{~m}$ triangular grid spacing using E55 vibrators. The extraction sequence was limited to $1.0 \mathrm{~m}$ with a compaction time of $40 \mathrm{sec}$ per step.

2. Surface compaction carried out according to a minimal number of 12 passes making 12 crossings using the 12-ton Broons impact roller type.

The geotechnical investigation carried out for this phase comprised of 2 drilled boreholes after the reclamation works and after the improvement works had been completed. Also post-compaction zone load tests including 3 large scale plate load tests were carried out using a $1.5 \mathrm{~m} \times 1.5 \mathrm{~m}$ plate and loaded to a maximum pressure of $300 \mathrm{kN} / \mathrm{m}^{2}$, post-compaction cone penetration tests were carried out in each $50 \mathrm{~m} \mathrm{x}$ $50 \mathrm{~m}$ square across the project site after compaction. The CPTUs carried out after compaction are relevant for evaluation of the geotechnical properties of the compacted fill and a minimum of two CPTUs have been carried out in each $50 \mathrm{~m}$ x $50 \mathrm{~m}$ square and the weighted average value are applied in the evaluation. Hence, the post improvement evaluation is basically based on the post compaction CPTU test results.

Current Pearl Jumeira sub-surface condition: Majority of the drilled post-compaction boreholes revealed SAND formation from elevation $+4.0 \mathrm{~m}$ to $-9.0 \mathrm{~m}$ DMD, followed by Silty SAND and Clayed SAND. It should be highly stressed that due to the limited number of post-compaction boreholes (thus SPT N-values) the pre- and post-compaction SPT $\mathrm{N}$-values do not reflect the actual improvement in this layer due to the conducted improvement process.

\section{GEOTECHNICAL DESIGN CONCEPTS AND BUILDING ZONE LAYOUT}

The Pearl Jumeira site has been divided into five (5) different building zones as presented in the building zone layout plan in Fig 2.

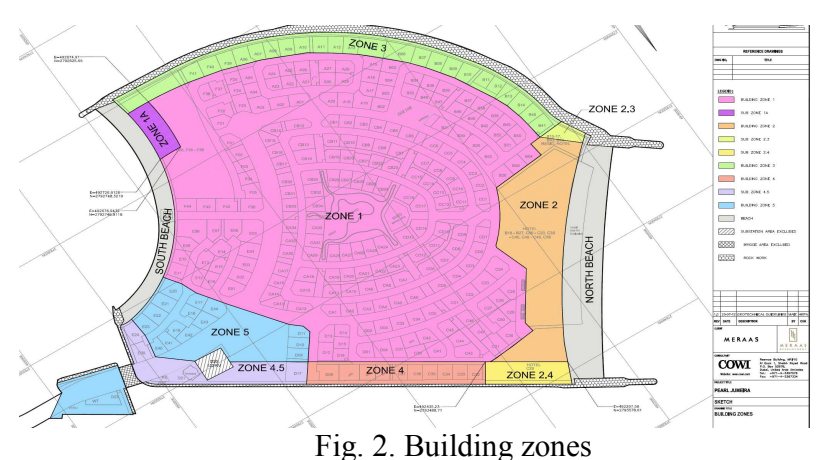

\subsection{Building Zone 1}

The area defined as building zone 1 represents the main part of the Pearl Jumeira and includes the following types of structures: residential villa $(\mathrm{G}+1)$, mosque, local plaza, and park. All types of foundations were used in this zone.

\subsection{Building Zone 2}

The area defined as building zone 2 is located on the North Beach and contains multi story hotels with/without basement and beach. All types of foundations were used in this zone.

Sub-Zone 2.3 This sub-zone is located between zones 2 and 3 and includes residential hotel plot adjacent to the revetment. The construction guidelines/constrains of zone 3 shall be the applied to this zone and the considered foundation types that can be used for the structures in this zone are strip footings and raft foundation only.

Sub-Zone 2.4 This sub-zone is located between zones 2 and 4 and includes a residential hotel plot. The construction guidelines of zone 4 shall be the applied on this zone and the considered foundation types that can be used for the structures in this zone are isolated 
footing, strip footing, raft foundation and pile foundation.

\subsection{Building Zone 3}

The area defined as building zone 3 is located on the southwest side of the island adjacent to the revetment and includes $\mathrm{G}+1$ single family residential villas. The construction guidelines of this zone are controlled by the expected settlement and the existence of a geotextile layer at certain depth. Strip footings and raft foundation have been considered in this zone.

\subsection{Building Zone 4}

The area defined as building zone 4 is located at the northeast side of the island and includes $\mathrm{G}+1$ residential villa. The construction guidelines of this zone shall be controlled by the stability of the flushing canal slope. All types of foundations were used in this zone.

Sub-Zone 4.5: This sub-zone is located between zones 4 and 5 and includes commercial buildings and mosques. The construction guidelines of Zone 4 shall be the applied on this sub-zone. All types of foundations were used in this zone.

\subsection{Building Zone 5}

The area defined as building zone 5 is located at the northeast side of the island and includes: residential $(\mathrm{G}+1)$, commercial/retail areas, mosque, and utilities. All types of foundations were used in this zone.

\subsection{Calculation of allowable bearing capacity}

Bearing capacity analysis: The calculations are carried out as bearing capacity calculations of shallow foundations according to Eurocode 7 [2][3] and should not be mistaken for the allowable bearing capacity; since the allowable bearing capacity requires settlement analysis of the foundations as well. The bearing capacity calculations are carried out assuming drained conditions with an effective friction angle of $\varphi^{\prime}=35^{\circ}$, which is conservative in relation to the granular revetment fill. The strength of the cohesive reclamation fill is as high as the granular reclamation fill in most building zones due to the cohesion. Only in building zones 4.5 and 5 it seems the strength of the cohesive reclamation fill $(\mathrm{CRF})$ is somewhat lower, but CRF layer is situated at $10 \mathrm{~m}$ depth or below in these areas and will therefore not affect the foundation bearing capacity. The marine silt clay (MSC) layer is also situated deep and will therefore not affect the foundation bearing capacity. Hence, bearing capacity calculations based on drained condition with $\varphi=35^{\circ}$ is justified.

Settlement analysis: The maximum bearing pressures for different shallow foundation sizes have been determined by settlement analysis assuming a maximum allowable settlement of $25 \mathrm{~mm}$ after 50 years for smaller footings and $50 \mathrm{~mm}$ after 50 years for larger raft foundations. The calculations include $10 \mathrm{~mm}$ allowance for accelerated settlements during seismic events; such that the actual settlements calculations are carried out for $15 \mathrm{~mm}$ and $40 \mathrm{~mm}$.

Allowable Bearing Capacity: The allowable bearing capacity of shallow foundations have been evaluated by comparing the maximum bearing pressures determined on the basis of bearing capacity and settlement evaluation respectively and the smallest of the two represent the allowable bearing capacity. It shall be noted that the recommended allowable bearing capacity values are restricted to the maximum allowable total settlement of $25 \mathrm{~mm}$ for isolated and strip footings and $50 \mathrm{~mm}$ for raft foundation including both static settlement (i.e., short and long term settlement) and the seismic induced settlement. If the designer opts to use higher allowable settlement/differential settlements, higher allowable bearing capacity can be determined and used subject to approval of the design by the relevant authorities and provided that all guidelines herein are followed. Furthermore, the plot owner may adopt/reach a higher allowable bearing capacity values for building zones 1 and 2 by conducting his own foundation soil interaction analysis for his particular structure requirement.

\section{LIQUEFACTION POTENTIAL}

Ground improvement was performed in the reclaimed granular fill of Pearl Jumeira Island to improve the strength and stiffness characteristics and to eliminate the risk of liquefaction during seismic events. Therefore, the island formations were well-designed against seismic hazards. The following sections present the methodology used to develop the ground improvement criteria of the reclaimed fill. It is noteworthy to mention that CPT tests were conducted in the island to validate such criteria after ground improvement works.

Liquefaction Analysis: Liquefaction analysis carried out for this project was based on methods defined in the summary report of the 1996 and 1998 NCEER and NCEER/NSF workshops [4]. Liquefaction resistance of sandy soils was evaluated based from CPTU results employing the approach proposed by Robertson and Wride (1998) [5]. The analysis is based from the calculation of two quantities required for assessing the liquefaction potential of the reclaimed fill. These quantities are: CRR (Cyclic Resistance Ratio) which expresses the capacity of soil to resist liquefaction, and CSR (Cyclic Stress Ratio) which is the seismic load on the soil by a given earthquake.

Cyclic Stress Ratio (CSR): The Cyclic Stress Ratio, CSR, profile caused by a design earthquake can also be calculated by the following formula:

$$
\operatorname{CSR}=\frac{\tau_{a v}}{\sigma_{v 0}^{\prime}}=0.65 \frac{a_{\max }}{g} \frac{\sigma_{v 0}}{\sigma_{v 0}^{\prime}} r_{d}
$$

Where, $\mathrm{a}_{\max }$ is the maximum ground surface acceleration; $\mathrm{g}$ is the acceleration due to gravity $(9.81$ 
$\left.\mathrm{m} / \mathrm{s}^{2}\right) ; \sigma_{\mathrm{vo}}$ and $\sigma_{\mathrm{vo}}^{\prime}$ are the total and effective overburden pressures at the depth under consideration before seismic stresses are applied; and $r_{d}$ is the stress reduction factor according to Blake as recommended by NCEER:

$$
r_{d}=\frac{\left(1.000-0.4113 z^{0.5}+0.04052 z+0.001753 z^{1.5}\right)}{\left(1.000-0.4177 z^{0.5}+0.05729 z-0.006205 z^{1.5}+0.001210 z^{2}\right)}
$$

Where $\mathrm{z}$ is the depth.

Magnitude Scaling Factor: For specific earthquake magnitudes M, the equivalent Cyclic Stress Ratio to a 7.5 earthquake magnitude $(\mathrm{CSRm}=7.5)$ can be determined by dividing the Cyclic Stress Ratio for the specific earthquake magnitude CSRm by a Magnitude Scaling Factor (MSF). The MSF proposed by Idriss and Boulanger (2004) [6] is considered in the analyses provided herein.

$$
M S F=10^{2.24} / M_{w}^{2.56}=1.76
$$

If the $\mathrm{CSRm}=7.5$ value exceeds the minimum Cyclic Resistance Ratio (CRR), then liquefaction is likely to occur.

Cyclic Resistance Ratio (CRR): The cyclic resistance ratio based from CPTU is calculated in accordance to Robertson and Wride (1998) [5].

Overburden Correction Factor, Kб: The overburden correction factor is calculated based on NCEER recommended equation is:

$$
K_{\sigma}=\left(\frac{\sigma_{v 0}^{\prime}}{P_{a}}\right)^{(f-1)}
$$

Where, $\sigma_{\mathrm{vo}}^{\prime}$ is the effective vertical stress; $P_{a}$ is the atmospheric pressure; and $f$ ranges from 0.7 to 0.8 for $D_{r}=40-60 \%$ and from 0.6 to 0.7 for $D_{r}=60-80 \%$.

Liquefaction-induced Settlement: The settlement due to liquefaction is estimated based on Figure 3.

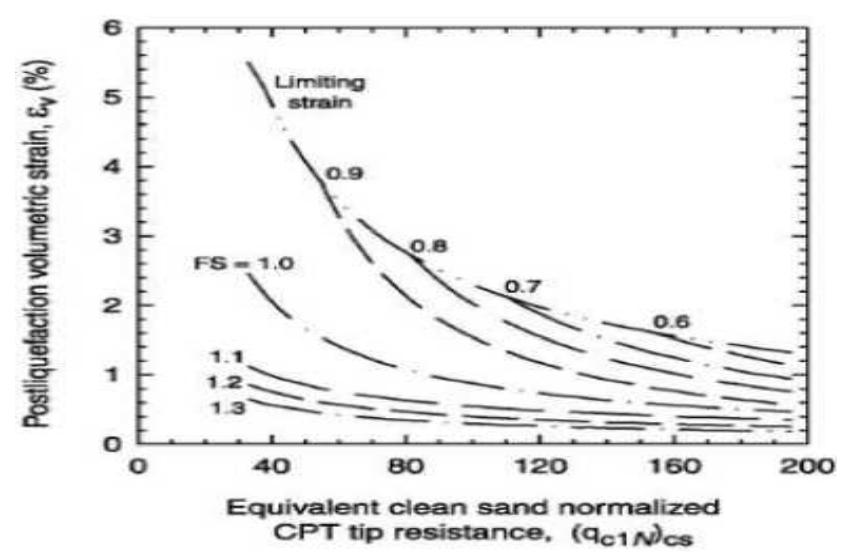

Fig. 3. Relationship between post liquefaction volumetric strain and equivalent clean sand normalized CPTU tip resistance for different safety factors

Seismic Loading: The seismic design level is considered according to Dubai Municipality and Dubai Authorities, the standard seismic level pertained to
Pearl Jumeira site has been identified and summarized in Table 2.

Table 2: Test conditions

\begin{tabular}{|l|l|}
\hline UBC 97 Seismic Zone & Zone 2A \\
\hline $\begin{array}{l}\text { Surface-wave Richter } \\
\text { Magnitude Factor, MS }\end{array}$ & 6.0 for 50 year-lifetime \\
\hline $\begin{array}{l}\text { PGA (Level-2 Earthquake) } \\
\text { for 50 year-lifetime }\end{array}$ & $0.15 \mathrm{~g}$ at bedrock level \\
\hline
\end{tabular}

Peak Ground Acceleration (PGA): PGA was considered at the surface as per Eurocode 8 [7]. The applicable design ground acceleration, a, at the surface shall be determined by multiplying the Peak Ground Acceleration at the bedrock (PGA) by ground type-based parameter depicted in the Eurocode 8 [8] The material above the cap rock consisted of compacted granular fill with thickness ranging from $10 \mathrm{~m}$ to $15 \mathrm{~m}$. Therefore, Ground Type E. The soil factor, $\mathrm{S}$, used for PGA amplification to surface level is also dependent on the earthquake's elastic response spectra. For earthquakes with magnitude greater than $\mathrm{Ms}=5.5$, Type 1 elastic response spectra is recommended by the Eurocode 8 [8]. For Ground Type E, the resulting soil factor, $\mathrm{S}$, is 1.40. The PGA at surface level for the compacted reclamation fill is calculated as: $\alpha=$ PGAS $=1.40 \times 0.15 \mathrm{~g}=0.21 \mathrm{~g}$.

CPT Performance Line: The CPTU Performance Line is an idealized theoretical CPTU values that is used as a basis for the execution and evaluation of compaction for the reclaimed granular fill. The Performance line is assumed for clean sand where a constant friction ratio of $\mathrm{fr}=0.25 \%$ and fines content of $5.0 \%$ were considered to generate the CPTU performance line against liquefaction. Figure 4 illustrates the graphical representation of the calculated CPTU Performance line against liquefaction considering the seismic loading calculated previously. As can be seen from the charts depicted in Figure 5, the adapted Performance Line guaranteed a minimum factor of safety against liquefaction of 1.25 .

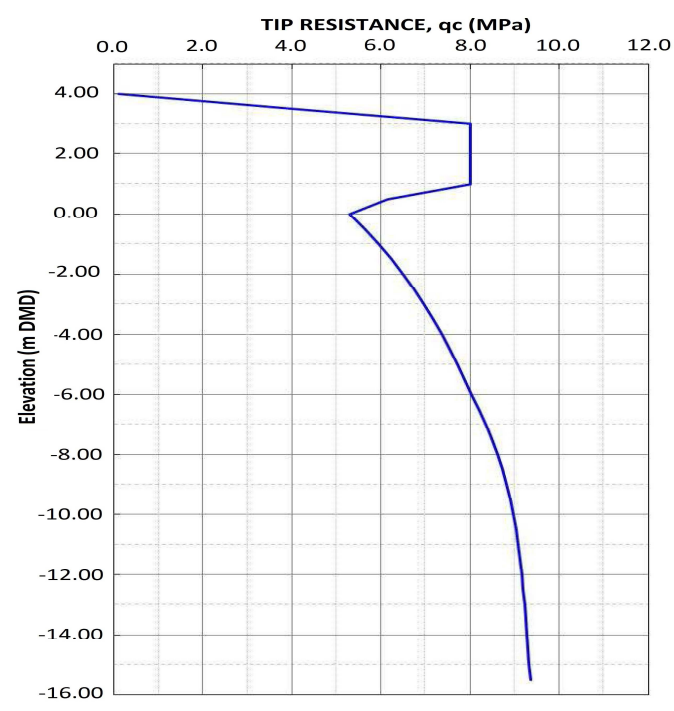


Fig. 4. CPT Performance Lines against liquefaction
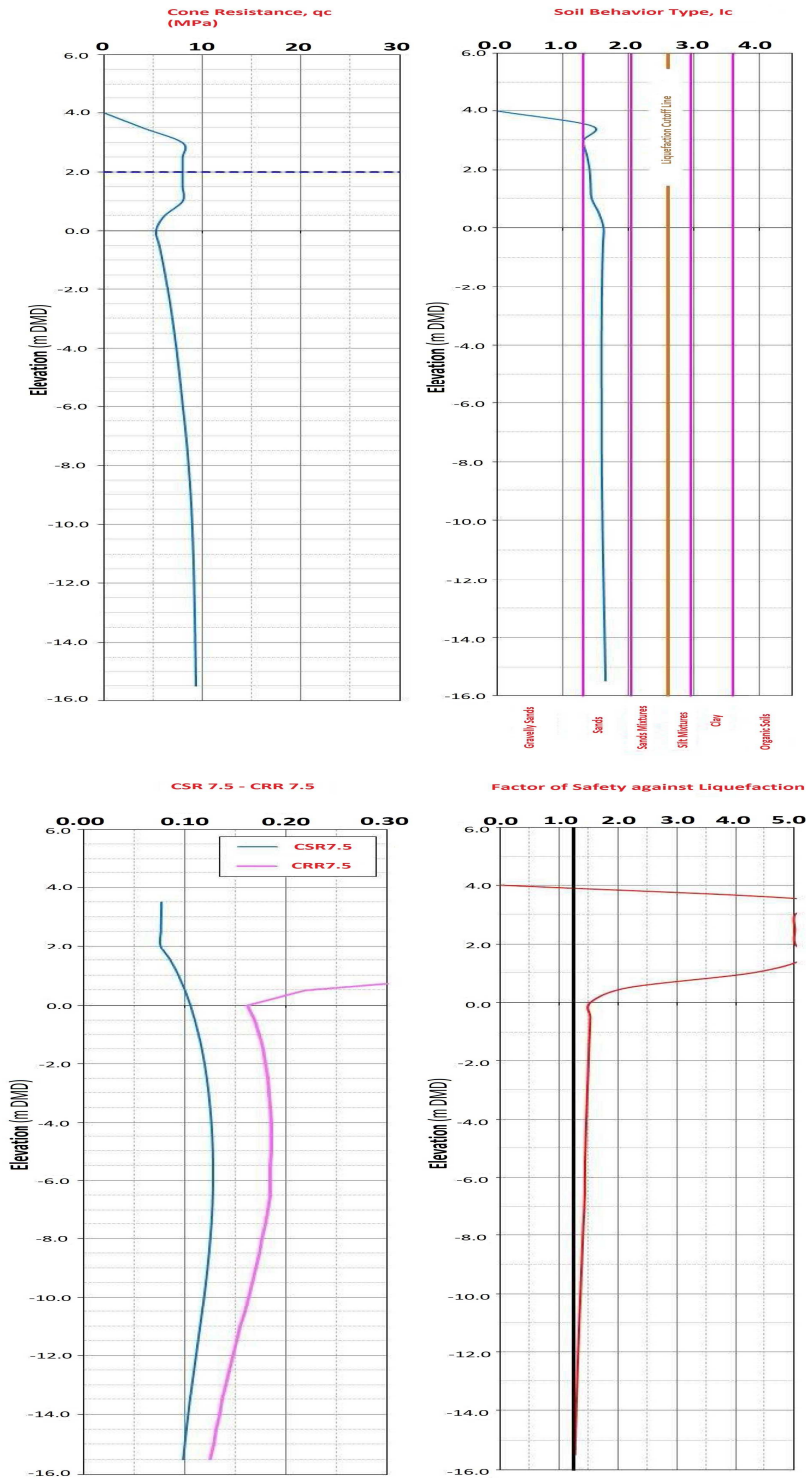

Fig. 5. Liquefaction analysis results of the CPTU

Liquefaction Analysis Results: All CPTU tests conducted in the Pearl Jumeira Island after vibro and surface compaction of the reclaimed granular fill have met the performance requirements

Seismic-induced Settlement: All CPTU tests conducted in the Pearl Jumeira Island were inspected for seismic induced settlements under the extreme seismic level summarized in the Table 2. The maximum calculated seismic-induced settlements always insured to be quite less than $10 \mathrm{~mm}$.

\section{SUMMARY AND CONCLUSIONS}

- The Pearl Jumeira is constructed from Dubai sourced reclaimed sand and locally sourced rockworks. The depth of the sea was between $10 \mathrm{~m}$ to $15 \mathrm{~m}$.

- Soil improvement was carried out using Vibro or Deep compaction followed by surface compaction.
- The ground improvement design was carried out to improve the stiffness of the fill material, reduce the long and short term settlements, and minimize the risk of liquefaction of the recently hydraulically placed sandy materials.

- Ground improvement works were carried out by an experienced contractor, testing was carried out before and after to control and measure the quality of the compaction works and the performance of the ground improvements.

- Vibro-compaction method was used for the deep soil improvement to achieve the required CPT performance line as per the approved criteria for this project and vibratory roller compaction was performed for the shallow improvement to achieve the $(95 \% \mathrm{MDD})$. The performances were measured using CPT, in-situ density and monitoring settlement of the fill.

- All post compaction tests were matching with design assumptions and requirements.

- There is no risk of liquefaction and the safety factor was more than 1.25 for seismic zone of $2 \mathrm{~A}$ and PGA 0.15 .

\section{ACKNOWLEDGEMENTS}

The Authors would like to thank Meraas Holding and Dubai Technology and Media Free zone Authority (DTMFZA) for their support and cooperation. Special acknowledgments to Mohamed Al Bahri from DTMFZA, Manish Tripathi from Meraas and Hussein Osman University of Sharjah (UoS).

\section{REFERENCES}

1) Pearl Jumeira Final geotechnical Assessment and design Report, January 2013, Meraas Development.

2) European Standard EN 1997-1, November 2004. English Version of Eurocode 7: Geotechnical design - Part 1: General Rules.

3) European Standard EN 1997-2, March 2007. English Version of Eurocode 7: Geotechnical design - Part 2: Ground Investigation and testing.

4) Liquefaction Resistance of Soils: Summary Report from the 1996 NCEER and 1998 NCEER/NSF Workshops on Evaluation of Liquefaction Resistance of Soils, ASCE Geotechnical and Geo-Environmental Engineering Journal, April 2001, Youd.

5) Robertson, P.K. and Wride, C.E. (1998): Evaluating cyclic liquefaction potential using the cone penetration test, Canadian Geotechnical Journal, 35(3), 442-459.

6) Idriss, I.M. and Boulanger, R.W. (2004): Semi-empirical procedures for evaluating liquefaction potential during earthquakes. Proceedings of the 11th International Conference on Soil Dynamics and Earthquake Engineering, Berkeley, 32-56.

7) Eurocode 8: Design of structures for earthquake resistance -Part 5: Foundations, retaining structures and geotechnical aspects, 2.

8) Eurocode 8: Design of structures for earthquake resistance Part 1: General rules, seismic actions and rules for buildings. 